\title{
ASSESSMENT OF THE IMPACT OF BUDGET DECENTRALIZATION ON SUSTAINABLE DEVELOPMENT OF TERRITORIAL COMMUNITIES IN UKRAINE
}

\author{
Ding Xin ${ }^{1}$, Tetiana Koliada² ${ }^{2}$ Ganna Muzychenko³
}

\begin{abstract}
Peculiarities of territorial community (hromada) development management are revealed and theoretical approaches to budget decentralization in Ukraine are substantiated. Based on the analysis of the composition and structure of local budgets, as well as the calculation of financial independence of territorial communities (hromadas), it is proved that the current budget system of Ukraine is characterized by a high degree of budgetary resources centralization, which does not provide real independence. Building an efficient model of fiscal decentralization consists in determining the tax potential of a separate administrative-territorial unit (territorial community). For further success of decentralization, it is necessary to determine the optimal amount of government functions that are appropriate and cost-effective to delegate to the appropriate local level on a permanent basis, thereby converting them into the local government's own functions.

Purpose of study. The aim of the study is to assess the impact of budget decentralization on the sustainable development of territorial communities (hromadas), to determine its relationship with changes in the administrativeterritorial structure of Ukraine and to strengthen the financial independence of newly established institutions (amalgamated hromadas).

Methodology. In the course of the research the following methods were used: analogy and comparative analysis to identify the features of the implementation of fiscal decentralization in different countries of the world and in Ukraine; settlement and constructive - used in determining the indicators of territorial communities' financial independence in the process of budget decentralization implementation in Ukraine; abstract-logical to reveal the main threats to the financial security of territorial communities and justify proposals and recommendations to ensure their sustainable development.

Results of the study. The study showed the presence of certain features in the implementation of budget decentralization reform in Ukraine in modern conditions due to a number of macroeconomic and institutional factors with a long-term and globalization nature of manifestation. They led to the emergence of clearly defined trends and patterns of change in the choice of regional development financial instruments, which will further improve the process of development management of Ukrainian administrative-territorial units in terms of decentralization to achieve the priorities of socio-economic development.

Peculiarities of territorial community development management are revealed and theoretical approaches to budget decentralization in Ukraine are substantiated. Based on the analysis of the local budget revenues composition and structure, as well as the calculation of the territorial community financial independence indicators, it was proved that the modern budget system of Ukraine is characterized by a high degree of centralization of budgetary resources. It has been substantiated that the difficulties arising in the financing of state budget expenditures under both unitary and federal systems are largely due to the imperfection or inconsistency of certain provisions of the Basic Law (the Constitution) with the current state of interstate relations and the domestic political situation.

Conclusion. It is emphasized that the main problem to be solved to build an effective and efficient model of fiscal decentralization is to determine the tax potential of a particular administrative-territorial unit (territorial community)
\end{abstract}

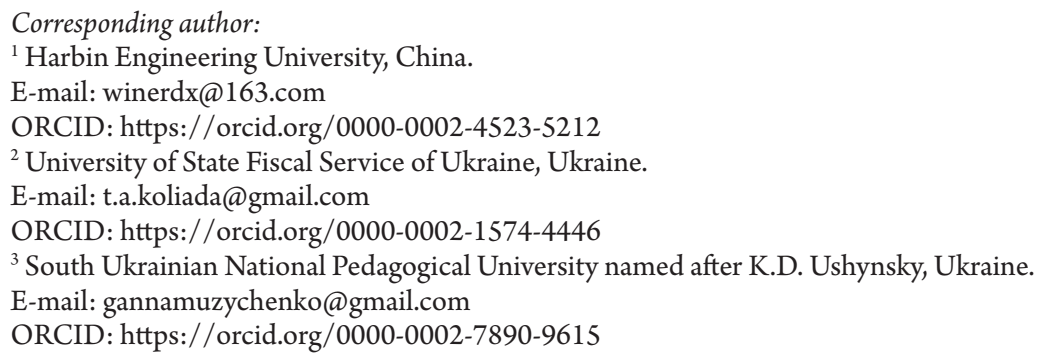


Vol. 7 No. 4, 2021

Baltic Journal of Economic Studies

and the optimal volume of state functions that are expedient and cost-effective to delegate to the local level as own functions of local self-government.

Key words: budget decentralization, community (hromada), amalgamated hromadas, sustainable development, hromada financial support, financial security.

JEL Classification: G28, H30, H41, H50, H72, H77, R12

\section{Introduction}

In modern conditions, a global trend in the sphere of public finance and state building is the strengthening of the institution of local self-government and the strengthening of its influence on social, economic and political processes in society. Ongoing reforms in Ukraine to decentralize power and strengthen the financial independence of local governments require an assessment of their effectiveness and efficiency in achieving these goals and long-term priorities.

Socio-economic development of the Ukrainian regions in conditions of integration with the European Union is modernized through the introduction of budget decentralization and granting greater autonomy to local authorities in addressing issues of their competence in accordance with European requirements. The reasons for the reforms are: low level of financial independence and economic and financial security of territorial communities (hromadas), disproportionate distribution and redistribution of funds between the state and regions, imperfect management of the formation and use of financial resources by territory. This leads to a slowdown in the balanced development of Ukrainian regions, which is especially reflected in the dynamics of hromadas development indicators, which are the main actors of socio-economic growth of the regions and the country as a whole.

Budget redistribution, which is accompanied by horizontal unification of hromadas throughout Ukraine, requires the development of an effective strategy to improve the financial situation in the country through the use of promising modernized instruments of the economy state regulation. It should be noted that the process of hromadas amalgamation should be in the interests of citizens, not just the state, thus ensuring positive changes in financial security indicators.

The research is theoretical and cognitive in nature and contains an analytical part. The authors use critical analysis of the thematic literature, metaanalysis, deductive and inductive reasoning, and comparative analysis using elements of time-series analytics (dynamics and structure change analysis). Due to objective obstacles to quantitative analysis, the assessment is qualitative in nature, with elements of inductive reasoning.

The analysis of recent publications on regional development, budget support of territorial communities and the formation of regional research methodology was carried out by scientists, in particular: D. Palma, G. Richardson, F. Perrault, M. Storper, R. Walker, B. Burkinsky, Z. Gerasymchuk, V. Chuzhikov and others. Methodological problems of socio-economic development of regions in the context of decentralization are reflected in the works of such foreign scientists as: A. Alcian, R. Barro, T. Veblen, E. Zolta, R. Coase, R. Musgrave, W. Oates, D. Romer, R. Solow, C. Tibou. The problems of improving the regional policy of regional socio-economic development in the context of decentralization and administrative-territorial reform are discussed in the works of Z. Varnaliy, T. Bondaruk, B. Danylyshyn, V. Kravtsiv, M. Melnyk, V. Miklovdy, and I. Storonyanska, O. Tishchenko, M. Khvesika, S. Schultz, and others.

\section{Decentralization as one of the key reforms for creating capable territorial communities (hromadas) in Ukraine}

The process of hromadas amalgamation in Ukraine began in 2014 due to the relevant amendments to the Tax and Budget Codes of Ukraine, which allowed in 2015 to demonstrate the first positive changes in the development of territorial communities as a result of their financial resources increasing. The way to implement decentralization is a very complex and long process to achieve a high level of economic development. There are many problems and acute moments on this path of implementation that seem strange to the population, but they are effective in the European value system. It is impossible to copy everything, as in the EU, but we must always remember that when choosing your own model of socio-economic development, you need to be more delicate and prudent.

The chronology of hromadas amalgamation for 2015-2019 is as follows (Figure 1). In 2015, their number was 159 amalgamated hromadas (AHs), in 2016 - 366 AHs, in 2017 - 665 AHs, in 2018 806 AHs, with each passing year the indicators increased. At the end of 2019, there were already 1,002, which includes 490 districts, indicating a significant breakthrough in the development of territorial communities (hromadas). Because budget funds are spent not only on the welfare of the state as a whole, but also directly on the prosperity and development of a large number of hromadas.

Looking at population trends (Figure 2), we can see that in 2015 there are $159 \mathrm{AHs}$ accounted for 1.4 million 


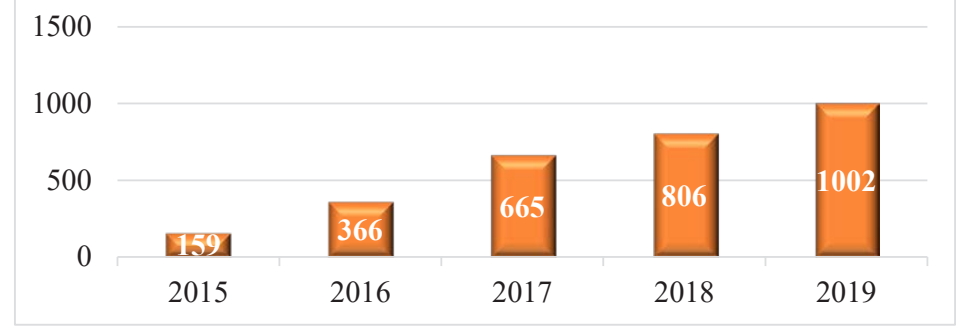

Figure 1. Number of Amalgamated hromadas

Source: own studied on the base on https://decentralization.gov.ua

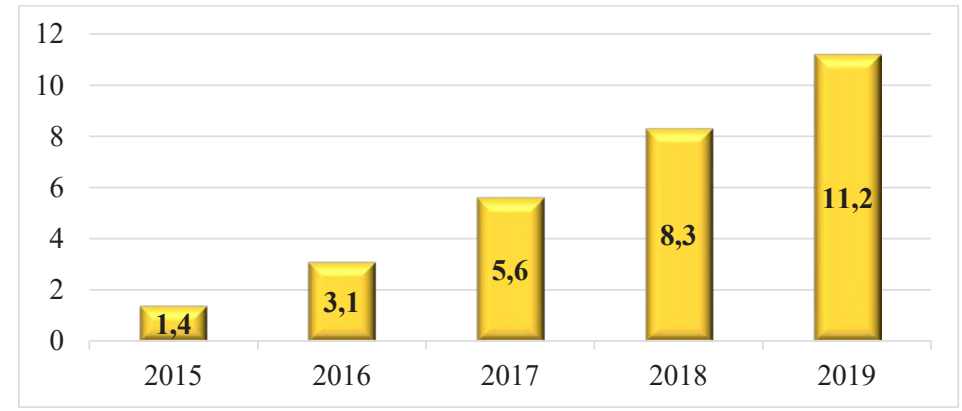

Figure 2. Number of inhabitants in amalgamated hromadas

Source: own studied on the base on https://decentralization.gov.ua

people, the number of AHs grew and the population increased in this area, in 2019 in 112 AHs lived 11,2 million people. This suggests that not all of Ukraine's population is moving to cities or abroad for a better life, and as their locality develops, they can work within their settlement.

The dynamics of area indicators also increased (Figure 3), in 2015 it amounted to 36.8 thousand $\mathrm{km}^{2}$ of the total area of the country, in 2016 89.6 thousand $\mathrm{km}^{2}, 2017$ - 167.5 thousand $\mathrm{km}^{2}$, $2018-193.5$ thousand $\mathrm{km}^{2}$, and today it is as much as 238.8 thousand $\mathrm{km}^{2}$.

\section{Local budget development trends for the period from 2014 to 2019 in Ukraine}

Based on the results of the monitoring of power decentralization and local government reform, let us analyze the local budget indicators dynamics and determine the trend of change for the period from 2014 to 2019.

As the revenue base of local budgets expands, the share in the gross domestic product (GDP) appears and increases. The share of local budgets' own revenues (general fund) to GDP in \% (Figure 4) grew at a fast pace, from 2015 to 2016 by $1.1 \%$, in other years growing slightly and decreasing each year by $0.1 \%$ from $0.3 \%$, but steady growth is progressing.

Own revenues of the local budgets general fund (Figure 5) also tend to increase. From 2015 to
2016 the growth was 48.4 billion UAH, and from 2018 to 2019 the growth decreased to 32.9 billion UAH, which is a satisfactory figure, the main thing is that this growth trend is working. That is, local authorities have sufficient financial resources to use effectively for community development.

Analyzing the performance of local budgets' own revenues for January-November 2019 compared to January-November 2018 (Figure 6), we see that there was an increase of $18-19 \%$, namely in the local budget by 37.8 billion UAH, and in the budgets of cities of regional significance by 15 billion UAH. We believe that this is significant progress in development, although in 2019 prices continued to rise with low official inflation in the country, but the competent distribution of funds provided by the decentralization reform of territorial communities (hromadas) shows a positive trend in territorial growth. Thus, by increasing the revenues of local budgets and increasing budget funding, it is possible to stimulate the development of infrastructure and more fully meet the needs of local communities (hromadas).

Looking at the per capita distribution of local budget expenditures (Figure 7) compared to 2018 and 2019, it is found that the main components of the distribution are: capital spending (by $11.1 \%$ increase), construction and regional development (by 40, 4\% increase), and housing and utilities (by $13.3 \%$ increase).

As Figure 8 shows, even with existing revenues and expenditures of local budgets, there is a balance. 
Vol. 7 No. 4, 2021

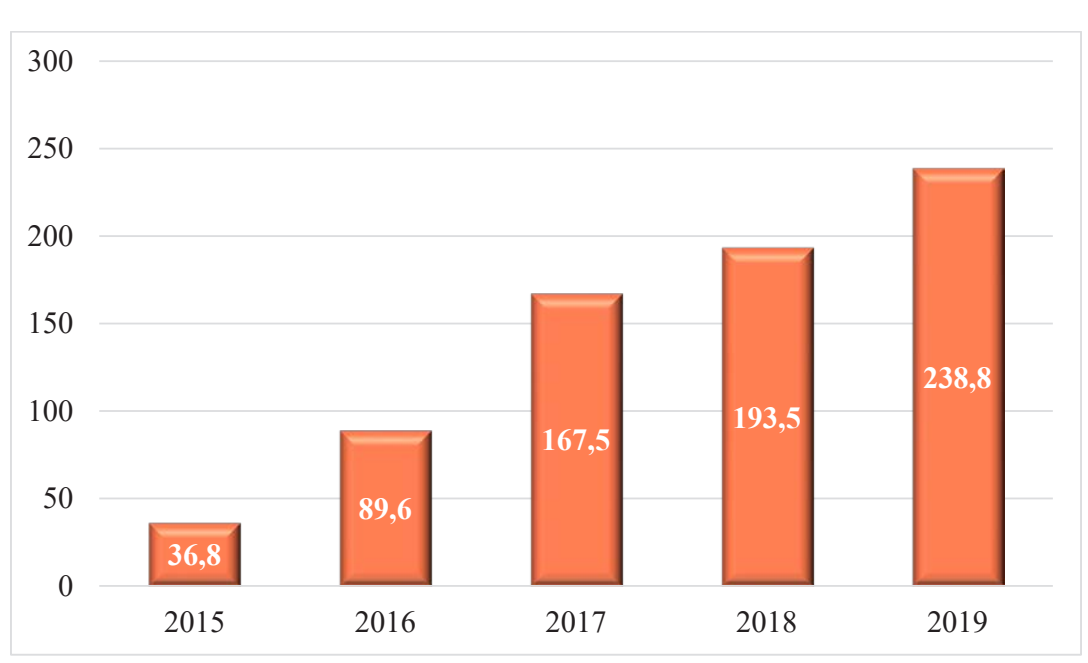

Figure 3. Quadrature of amalgamated hromadas (thousand $\mathbf{k m}^{2}$ )

Source: own studied on the base on https://decentralization.gov.ua

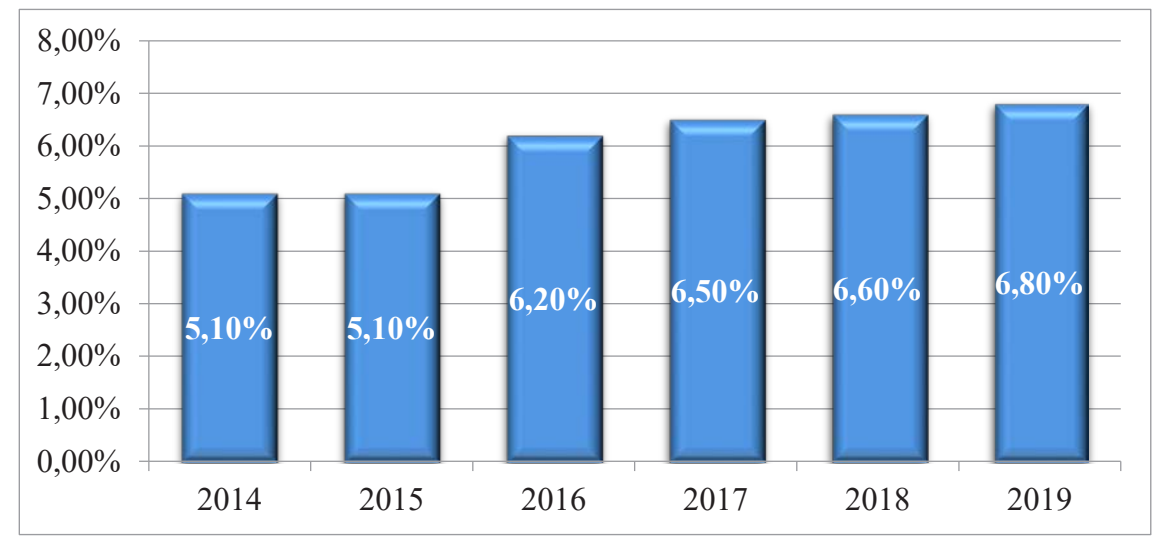

Figure 4. Share of local budgets own revenues (general fund) in GDP, in \%

Source: own studied on the base on https://decentralization.gov.ua

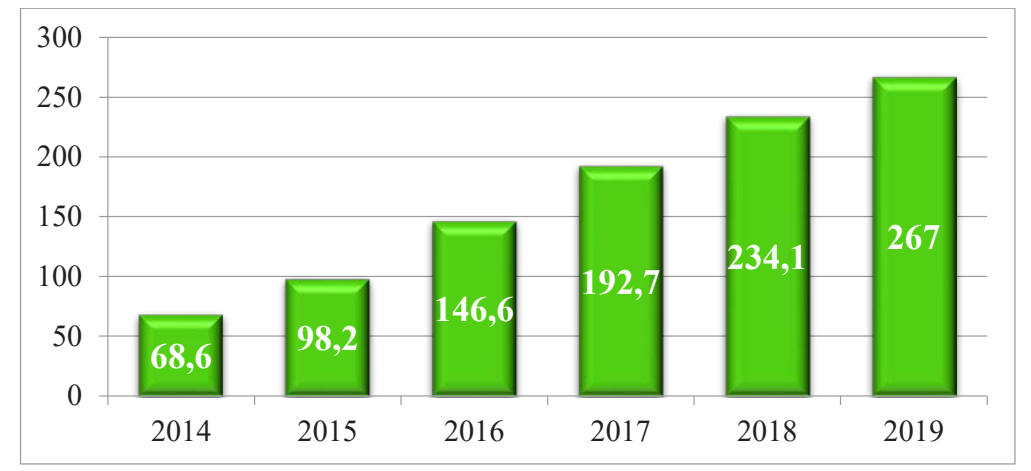

Figure 5. Own revenues of the local budgets general fund, billion UAH

Source: own studied on the base on https://decentralization.gov.ua

This indicates that the data on the financial capacity of amalgamated hromadas are trying to make it as transparent as possible and show that there is a balance on the accounts. The balance of local budgets of Ukraine (Figure 8 ) decreased by half in the period from $11 / 1 / 2019$ to $12 / 1 / 2019$.
At the same time, the balances of 806 amalgamated hromadas (Figure 9) decreased slightly, by UAH 0.4 billion.

Thus, it can be supposed that there are too many funds for the population' needs and community support, but this is a false assumption. In fact, there 


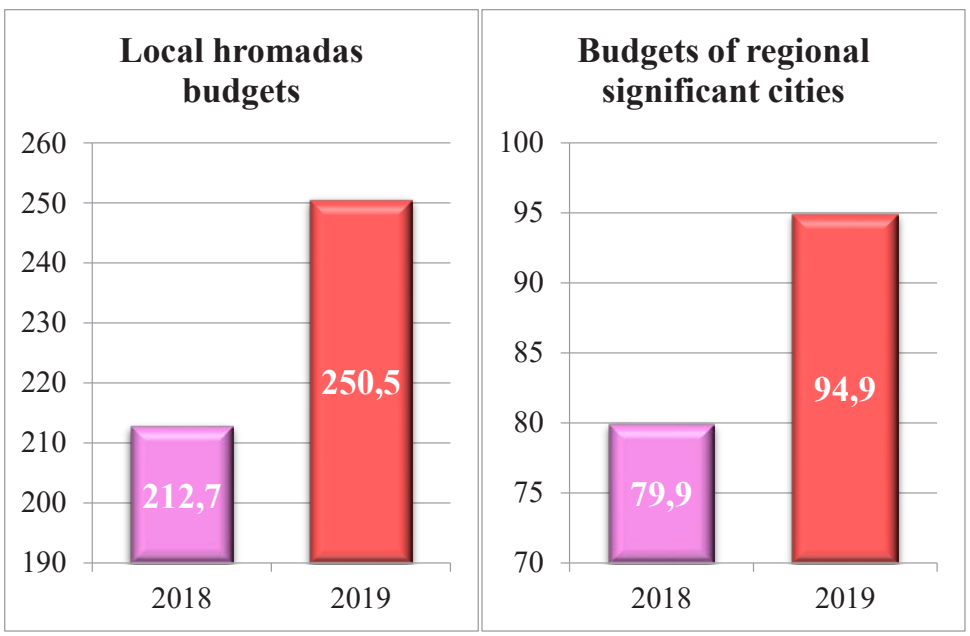

Figure 6. Execution of local budgets own revenues, billion UAH (\%)

Source: own studied on the base on https://decentralization.gov.ua

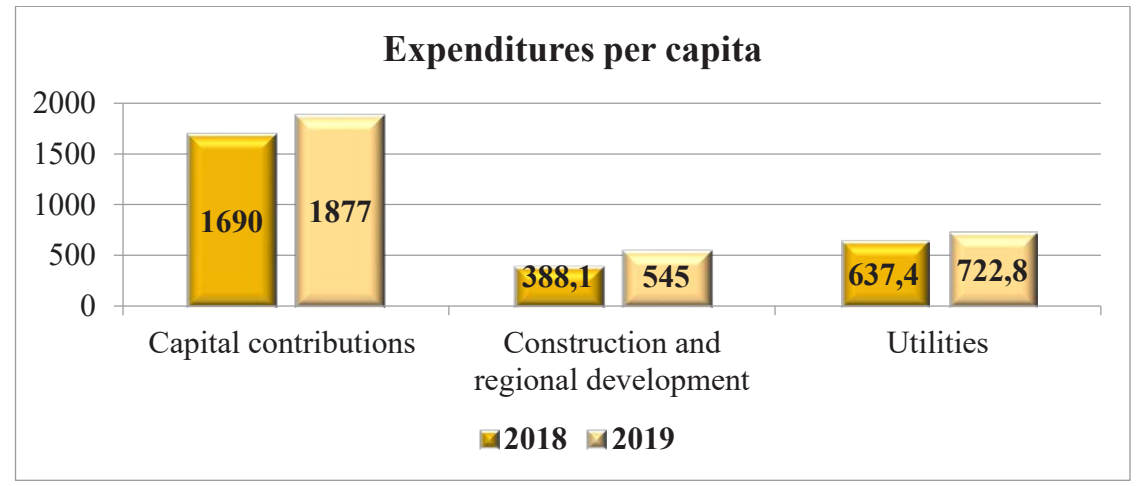

Figure 7. Dynamics of local budget expenditures for 2018-2019

Source: own studied on the base on https://decentralization.gov.ua

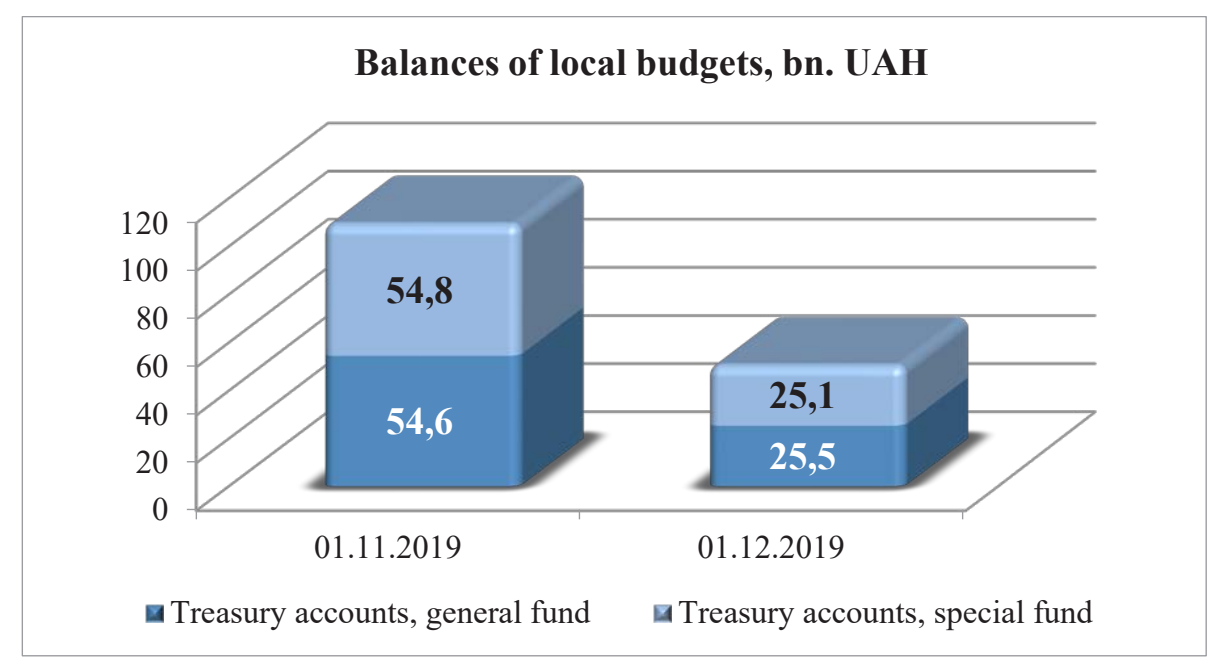

Figure 8. Balances of local budgets, bn UAH

Source: own studied on the base on https://decentralization.gov.ua 


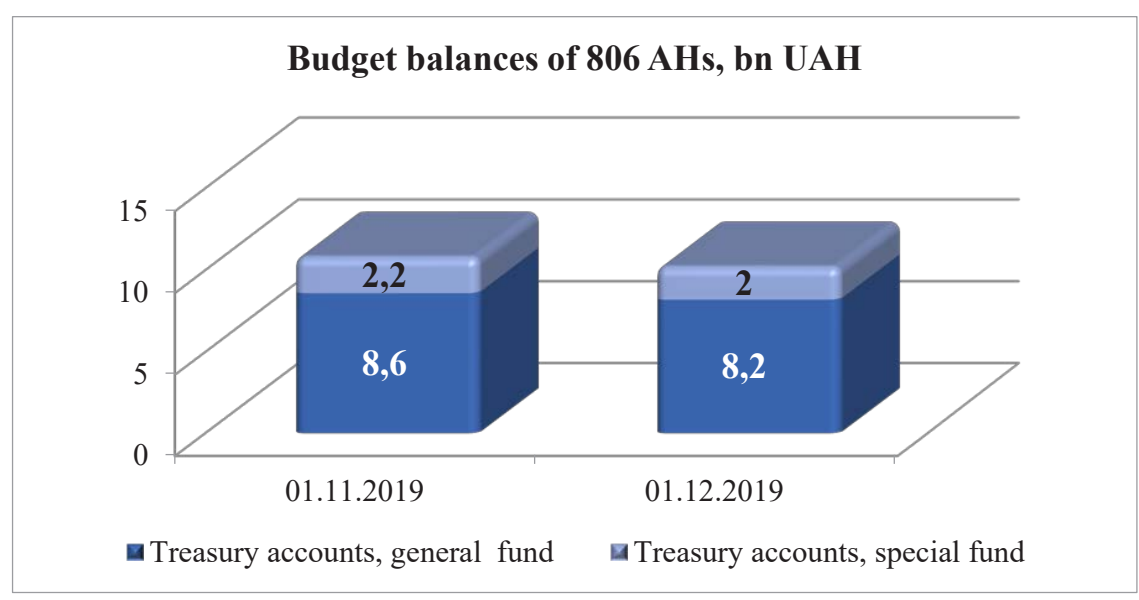

Figure 9. Balances of $\mathbf{8 0 6}$ amalgamated hromadas budgets, bn UAH

Source: own studied on the base on https://decentralization.gov.ua

is a discrepancy between each period's expenditures for the same needs, so a balance is formed.

Regarding the amount of state support for territorial communities (hromadas), indicators show that the state has increased the amount of financial support for AHs (Figure 10). Thus, if in 2014 support for socioeconomic development amounted to 0.5 billion UAH, in 2018 the amount of support was 19.37 billion UAH, and in 2019 - 20.75 billion UAH, which is 41 times more than in 2014.

As for the volume of public aid to regions in order to support socio-economic development, a rating of state financial assistance to local and regional development was compiled, in which 24 regions (except for the Autonomous Republic of Crimea). The first 5 oblasts are: Donetsk - 1,064 million UAH, Lviv - 907 million UAH, Dnipropetrovsk 881.1 million UAH, Odessa - 809.4 million UAH, Ivano-Frankivsk - 738.7 million UAH. These funds supplement the local budget and are designed to improve and renew the infrastructure of the local community. Particular attention is paid to the Donetsk Oblast, as there are military operations and the local community needs more help.

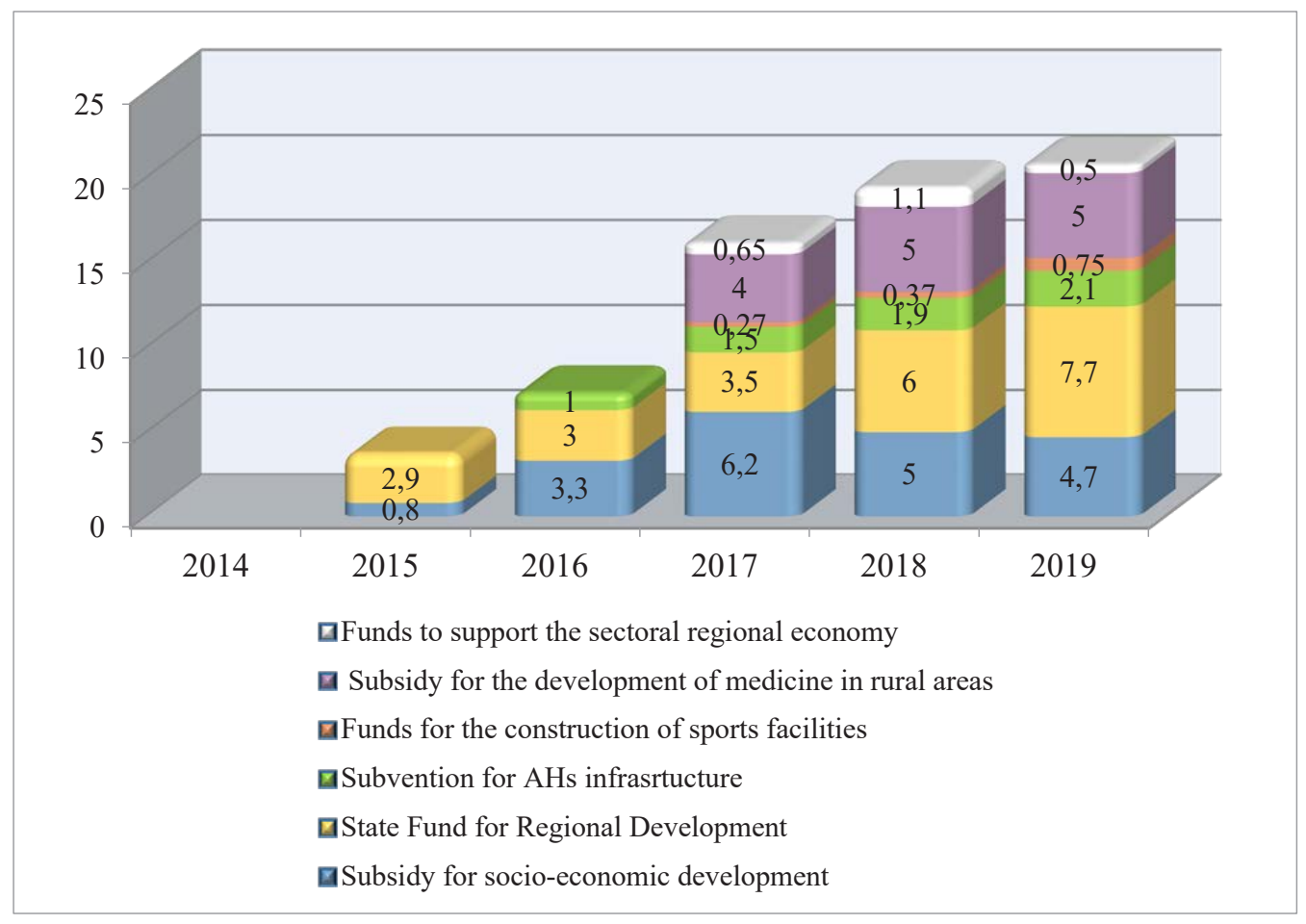

Figure 10. State financial support of local and regional development, billion UAH

Source: own studied on the base on https://decentralization.gov.ua 
To meet a certain level of territorial security needs, a clear list of priorities and objectives is calculated to achieve it, in order to avoid threats of financial resources loss that may arise in the process of implementing the objectives. The search for ways to increase financial resources is for local governments to find alternative sources, sides of the local communities in which to invest in order to increase profits from this area.

Under the conditions of turbulent economic development caused by the spread of the COVID-19 pandemic in most countries of the world and the introduction of restrictions on border crossings for both people and goods, such factors as the balanced development of Ukrainian regions, the main actors of socio-economic development of regions and the country as a whole are slowing down.

\section{Hromadas' financial independence level}

There is a need to assess the impact of budget decentralization on the hromadas' financial independence level by calculating the relevant indicators.

Analytical calculations will make it possible to determine the dynamics and trend of development of hromadas with regard to the financial independence of local budgets from the volume and types of transfers from the State Budget of Ukraine. In particular, the financial dependency ratio was calculated, which is defined as the share of subventions from the State Budget of Ukraine in the revenues of local budgets; the budget decentralization ratio; the expenditure decentralization index as the share of local budgets in the expenses of the Unified Budget; the modified expenditure decentralization coefficient as the share of local budgets in the expenses of the Unified Budget (not including military spending). The results of the calculations are given in Table 1 .

These calculations show that in 2016 local budgets were the most financially dependent on the state budget. In the conditions of the ongoing process of budget decentralization in Ukraine, there is a trend to increase the financial independence of local budgets. As you can see, in 2018 local budgets were more financially independent of the state budget, but in 2019 the trend changed to the opposite (Koliada, 2018).
As for the coefficient of budget decentralization, it is one of the most important indicators which shows the ratio of local budget expenditures (excluding intergovernmental transfers) to GDP. The values of this indicator reflect the part of financial resources that is distributed among local governments. According to the normative indicators, if the indicator is below $10 \%$, the level of decentralization is low; $15-10 \%-$ average; $15 \%$ - high. That is, in 2016 - the level of budget decentralization was average; in 2017-2018 high, but in 2019 - low.

In addition, during 2017-2018 there is an increase in the modified coefficient of budget decentralization by expenditure. However, in 2019 the ratio returns to the level of 2016. The lowest coefficient of decentralization by expenditures was in 2019 (41.2\%).

The subjects of the financial system, determining the needs of communities in accordance with their interests, design a development strategy that ensures their self-improvement and independence, taking into account the interests of not only the state, but also the population. At the same time in Ukraine there is a significant differentiation in the volume and quality of public goods at the level of settlements, regions, cities, etc. Some regional centers have much more useful and necessary infrastructure than cities with small populations. We can examine the public goods of a particular territorial community (hromada) according to the rating of state financial support for local and regional development.

Thus, the living conditions in districts and villages are being improved by age categories from the youngest to the oldest inhabitants. This is only because priority needs ranking is used and financial security metrics are monitored. Although there has been misuse of budgetary funds over the years because corrupt schemes still work, we are already making progress in understanding the people of the country that it is necessary for their good. Corrupt practices are a type of threat to financial security that affects not only the local community (hromada) itself, but also local businesses and the state as a whole. This is why financial literacy needs to be introduced and taught to different age groups in order to improve their well-being and living conditions in the country.

Table 1

Dynamics of territorial communities' financial independence indicators in the process of decentralization budget implementation in Ukraine for 2016-2019

\begin{tabular}{|c|c|c|c|c|}
\hline Indicator & 2016 & 2017 & 2018 & 2019 \\
\hline Coefficient of financial dependence, $\%$ & 51,5 & 49,9 & 48,7 & 41,8 \\
\hline Index of budget decentralization, $\%$ & 14,5 & 16,4 & 15,8 & 8,1 \\
\hline Modified multiplier of decentralization of expenditures, \% & 44,6 & 49,9 & 48,8 & 44,7 \\
\hline Quotient of expenditures decentralization, \% & 41,4 & 46,4 & 45,1 & 41,2 \\
\hline
\end{tabular}

Source: calculated by the author according to the State Treasury Service of Ukraine www.treasury.gov.ua 
To better understand the financial interests of local communities (hromadas), we suggest characteristics such as:

- compliance with the collective bargaining agreement to prioritize community needs and modernize old needs to improve the economic condition of the territorial community (hromada);

- the factor of provision is financial security in the manifestation of the reproduction of goods in the form of social and economic indicators;

- due to the distribution of financial resources between territories, there is a threat of high competition, which should be minimized by indicators of improving the lives of the population and increasing the territorial community's (hromada) own income;

- minimizing the negative impact of threats while ensuring the financial interests of the community.

The mechanism of protection against threats in the implementation of certain goals requires not only control over the execution of specific tasks, but also the targeted use of financial resources with the involvement of a professional specialist in financial control and security. For this purpose, the Concept of Local Government and Territorial Organization of Power Reform in Ukraine was created, which aims to provide quality and public services, the fruitful work of government and local self-government in general. To achieve all the objectives of this concept, it is allowed to expand the boundaries of financial independence of local self-government in order to improve their own economic situation. Such innovations will protect and act not only in the interests of a particular territorial community (hromada), but also public finances in general.

We believe that it is necessary to set strategic goals for 5 years, and at the end of each year to summarize and modernize the goals in accordance with changes in the economy. This will have a positive impact on the development of the territory, the state and will highlight significant improvements. This is exactly the term for setting goals, because over 5 years you can gradually introduce new ideas, methods and techniques, track their development and the trend of changes in certain indicators. Reporting should be a prerequisite, as it is only through monitoring that work is constantly progressing. Any financial and economic development of an enterprise has risks and threats to sustainable growth. To avoid or minimize these threats, it is necessary to calculate the degree of impact and the probability of possible losses, so that there are no uncontrollable fluctuations in sustainable development.

If the responsibility for the financial performance of a local government body is delegated to state power, then the principle of power and competence division between the levels of government will not be respected and certain goals for the development of territorial communities will not be achieved. When local government representatives are aware of the seriousness of their actions, then there is a real potential to create something better than in other local communities (hromadas), and the method of competition continues to work. The main thing at this stage is not to forget about financial security, the result and quality of public services.

As for budget decentralization, it has clear goals for improving the work of local governments and transparent accounts of local and regional funding. We have indicators for which there are people who are trying to fulfill their direct responsibilities and improve the lives of the population and the state as a whole.

Note that there is no separate body (unit) that oversees only financial security, with the result that responsibility for financial resources and interests is taken over by local governments, which are forced to make changes to the legal framework or take over responsibility. These changes create imbalances and destroy financial security, as there is a lack of transparency in the provision of information to consumers of public services and a low level of financial literacy of the population. Due to the significant differentiation of territorial communities' financial potential, the central executive authorities must objectively prevent by law the emergence of horizontal fiscal imbalances, with the strengthening of some communities' financial security occurring at the expense of others or weakening the financial security of the country as a whole. The key in this process is that the mechanism of inter-territorial redistribution of financial resources works, which was not envisaged in the first stages of the creation of territorial communities.

\section{The interdependence of local hromadas and state financial security}

The interdependence of population and territory financial security affects the countries' financial security. The last years of the future vertical construction of financial security is provided at the expense of this and horizontal construction of this system, because it requires a rational and independent vertical construction. Currently, economic entities use only those scales and tools that are specified in the legislation. If necessary, allow "to manage the situation, to influence the situation" (which is etymologically contained in the change of the term "security") is absent in local communities when it comes to the principles of customs policy, the functioning of financial, monetary, credit risks. This conclusion follows from Article 92 of the Constitution of Ukraine, which provides for a single influence on certain areas of state law. Therefore, we cannot agree with those scientists who consider monetary, currency and banking, stock, customs 
and tariff, and inflationary security in the structure of the region's financial security (Medvid 2007; Karpinsky, 2008).

There are objective limitations on the influence of individual financial security entities, namely territorial communities, on determining the priorities of national economic policy. At the same time, we believe that the formation of priorities for certain components of financial security, namely fiscal, investment and debt security, depends on the actions and decisions of local communities (hromadas) and local governments.

Article 143 of the Constitution of Ukraine states that territorial communities through local selfgovernment have the power to manage communal property; approve the programs of socio-economic and cultural development and control their implementation; formation, reorganization and liquidation of municipal enterprises and organizations, etc., these are all principles of the investment market, which are defined by law. In other words, territorial communities can participate and influence investment processes, despite the lack of investment market principles stipulated by Ukrainian legislation (Constitution of Ukraine).

Threats and risks to financial stability need to be anticipated for the future forecast of sustainable development. This minimizes their negative manifestation in the future or identifies ways to minimize the loss of their impact. Therefore, the main thing in the mechanism of financial security is to identify and structure events, phenomena, processes that may be a threat to sustainable socio-economic development of the state and, accordingly, to meet the social needs of territorial communities. Threats need to be identified quickly so as not to trigger an intensification of the process.

The threat of financial imbalance to the territorial community testifies, among other things, to the insufficient level of legal support for the functioning of local government in the country. There are criteria by which you can identify the risks that arise in the legal field, namely:

1. The uncertainty of mechanisms for organizing the activities of territorial communities and clear economic rights. Therefore, it is difficult to fully realize their economic rights.

2. Inconsistencies in the provisions of various legal and regulatory acts. For example, local governments have such risks as: poor execution of powers, underfunding of territorial needs, improper redistribution of budgetary resources, hidden deficits of funds, and credit indebtedness of local budgets.

3. Contradictory legal norms, namely the financial support of territorial communities (hromadas). A striking example is the administration of the single tax paid by local communities (hromadas), charged on:
- the special fund of local budgets (in 2014);

- the special fund of the State Budget of Ukraine (in 2017);

- the general fund of local budgets (other periods).

Territorial communities function as subjects of a single economic system, so they are characterized by a different type of threats to financial security. In particular, the following threats can be distinguished:

1. The dependence of funding for the current development of the territorial community on the volume of transfers in the local budgets' revenues.

2. Social instability among the population due to political events.

3. Depopulation of the territorial community.

4. Weakening of the investment climate.

5. Significant probability of natural and man-made threats.

The source of threats to the territorial community financial security are external factors that regulate the economic policy of central authorities. The specialty of community functioning is to minimize the threats of internal factors. Such threats include:

1. Ineffective structure of the territorial economy.

2. Independent state of communal infrastructure, which exists in all regions of the country.

3. Insufficient resources for the development of territories and regions in general. In Ukraine there are no public registers of communal property belonging to individual communities, for most settlements their territorial boundaries are not defined, the mechanism of communal property inheritance is not ensured. This situation, along with the lack of effective mechanisms of control over the activities of local authorities by local communities, leads to irrational use of communal property, inefficient economic activities of local councils, raiding and mass illegal alienation of communal property (Territorial community 2016: 42).

4. Low level of financial literacy, social activity, public consciousness.

5. Lack of a strategic plan for the activities of local self-regulatory bodies.

The need to confront threats to the financial security of local communities is undeniable. The success of implemented measures depends on the completeness and timeliness of their implementation, as well as on a clear awareness of such threats among financial security subjects. Note that the list of threats to the economic and financial security of the state is contained in the National Security Strategy of Ukraine (Strategy 2015). With regard to financial security, regulations have not been considered, although this would reduce the number of threats. To improve performance and efficient use of funds was calculated assessment of the development strategy, namely through SWOTanalysis. This indicator makes it possible to calculate the strengths and weaknesses of economic entities and identify threats to financial security. If the above 
actions are followed, the territorial communities (hromadas) will function effectively and fully perform their functions and tasks, and financial resources will be used for their intended purpose without corruption schemes and other threats.

\section{Conclusion}

Thus, decentralization is a key reform and mechanism for creating affluent territorial communities (hromadas) and ensuring sustainable regional development in Ukraine.

Priority issues that need to be addressed in the decentralization process are - determining the list of tasks (scope of functions) to be performed by the central government and assigned to local authorities, as well as the legislative consolidation of revenue sources necessary to form their own budgetary resources for their implementation.

Therefore, we emphasize the need for all responsible persons to fulfill their functional duties in order to improve the life not only of their territorial community (hromada), but also of the state' s population as a whole. It is not for nothing that local communities (hromadas) have created local self-government bodies to make it easier to assess the needs of a certain territory and monitor their implementation. In connection with the implementation of the budgetary decentralization policy, the division of responsibilities for control and monitoring of financial security, not only at the local, but also at the national level, is relevant.
Financial security is characterized by threats of various phenomena, events and processes that hinder the effective functioning of local governments, as well as the development of territorial communities (hromadas). Apply strategic plans and calculations of possible threats, using the SWOT analysis evaluation method, which shows the strengths and weaknesses of the strategic development of financial security and possible threats.

Thus, there is a need to study and research this topic in order to improve the functioning of the system for monitoring the financial security and economic condition of the state and united territorial communities even in difficult political conditions. Such measures will make a rational choice of the real needs of the territorial community (hromada), set realistic priorities, contribute to a certain level of financial security and sustainable economic development in general.

Further research in this area consists in determining the tax potential of a particular administrative-territorial unit and the optimal volume of state functions that are expedient and economically profitable to delegate to the appropriate local level on a permanent basis, thereby transferring them into the own functions of local government and ensuring the real independence and financial security of territorial communities.

\section{Acknowledgement}

This research is supported by Chinese-Ukrainian Cooperation Fund of Harbin Engineering University.

\section{References:}

Encyclopedic dictionary of public administration (2016). Kyiv: NAPA.

Monitoring of the process of decentralization of power and reform of local self-government (2019). Available at: https://decentralization.gov.ua/uploads/library/file/494/10.11.2019.pdf

Development of budget decentralization in Ukraine: scientific report (2016). Available at: http://ief.org.ua/docs/ sr/292.pdf

Annual report on the execution of the State Budget of Ukraine for the relevant year (2020). Available at: https://www.treasury.gov.ua/ua/file-storage/vikonannya-derzhavnogo-byudzhetu

Muzychenko, G., Koliada, T., \& Churkina, I. (2017). Impact of European integration processes on the necessity of long-term budget planning introduction in Ukraine. Baltic Journal of Economic Studies, 3(5), 329-333. Available at: http://www.baltijapublishing.lv/index.php/issue/article/view/303/pdf

Constitution of Ukraine (1996). Available at: http://zakon.rada.gov.ua/laws/show/254\%D0\%BA/96-\%D0\% $\mathrm{B} 2 \% \mathrm{D} 1 \% 80$.

Medvid, M. M. (2007). Financial security of the regions of Ukraine. Poltava.

Karpinsky, B. A. (2008). An integrated indicator of the balance of the financial system of Ukraine in terms of financial security. Scientific Bulletin, 18.2, 131-145.

Territorial community as a basic link of the administrative-territorial structure of Ukraine: problems and prospects of reform (2016). Kyiv: NISR.

National Security Strategy of Ukraine (2015). Available at: http://zakon.rada.gov.ua/laws/show/287/2015

Koliada, T. A. (2014). Features and prospects of budget decentralization in Ukraine. Journal of Corporate Management and Economics "Maneko", 2, 229-238. 